\title{
COMPUTER SCIENCE AND CODING STUDY PATHS FOR WOMEN, MATURE WORKERS, AND MINORITIES: MOOC OR UNIVERSITY - WHO DOES IT BETTER?
}

\author{
Mathew Lane ${ }^{\mathrm{a}}$, Wendy Hui ${ }^{\mathrm{b}}$, Karen Murcia ${ }^{\mathrm{b}}$ and Pornpit Wongthongtham ${ }^{\mathrm{b}}$ \\ ${ }^{a}$ Diversus, West Perth, Australia \\ ${ }^{b}$ Curtin University, Perth, Australia
}

\begin{abstract}
This article is an exploratory analysis and comparison of the demographic distributions of data collected from the 2016 New Coder Survey, with that obtained from the Integrated Postsecondary Education Data System (IPEDS). In comparing the data sets, the findings suggest that overall females were more likely to engage in online self-paced coding education, particularly when they had no background or previous study in an IT discipline. This contrasted strongly with females having an existing IT qualification. When looking at ethnicity, the research identified that those students who identify as an ethnic minority were more likely to undertake formal tertiary education in IT, rather than engage in online coding study. The research also confirmed that the average age was higher, and diversity of age groups was larger for those undertaking online study, when compared with those undertaking formal tertiary study. The practical implications of this analysis to diversity in Information Technology disciplines such as computer science, and more broadly with STEM-related disciplines are discussed.
\end{abstract}

\section{KEYWORDS}

STEM, Education, Ethnic Minority, Diversity, Coding, Information Technology, Gender Bias, Ageism

\section{INTRODUCTION}

If effectively managed in the workplace, diversity can help encourage creativity and innovation (Østergaard et al 2011), improve team performance (McLeod et al 1996), and identify new product and market opportunities (Robbins 2004, Bourgeois 2018). Therefore, it is important that the education sector embraces diversity to produce talents who are committed to diversity (Bial 2016, Bourgeois 2008). Aside from economic benefits, diversity in the workplace and education is also considered a key aspect of social justice (Sue 2008, Ayers et al. 2008). 
IADIS International Journal on WWW/Internet

However, despite continued efforts in equal opportunity, we continue to witness underrepresentation of minority groups undertaking tertiary study in various subject areas and, in particular, computer science. For example, in the US, the percentage of females awarded with a bachelor's degree in computer science increased from $13.6 \%$ in $1970-1971$ to $37 \%$ in 1983-1984 but gradually declined to $18 \%$ in 2010-2011 (Kendall 2017). Both enrolment and completion rates in computer science are lower for females than males (Miliszewska et al 2006). In terms of ethnicity, Taylor and Ladner (2012) show that there is little improvement between 2000 and 2009 in the problem of underrepresentation of some ethnic groups (African Americans, Hispanics, and American Indian or Alaska Natives) in the field of computing. A more recent study shows that ethnicity and gender gaps continue to persist in computer science education (Google Inc. and Gallup Inc. 2016). Similar problems are observed in other parts of the world including the UK, New Zealand, Australia and South Korea (Glick 2017, UNESCO 2017).

Ageism is another major diversity concern in the IT sector. Castillo (2017) reports that many over 40 find it hard to find a job in the industry. More than $40 \%$ of IT workers worry about losing their jobs because of age (Sumagaysay 2017). Several real examples of ageism in recruitment in video game development are outlined in Serrels (2018). In fact, many tech giants such as IBM, Amazon, Facebook and Intel are now facing charges or being investigated for ageism (Mcintyre 2018, Claburn 2018, Wells 2018)

There is currently a downward trend in the availability of jobs involving routine tasks: Routine manual roles in industries such as construction, mining, agriculture etc. are being supplanted by automation (Corday 2014, Leggatt 2016, Ali 2001), whereas routine cognitive roles, such as administration tasks, book keeping, call centres etc. are either being coded into rules and workflow of business computer systems, or the roles are being sent offshore to be conducted at a fraction of the cost (Autor 2010).

Greater job security, as well as real growth is evident however, in non-routine functions (Heath 2016), which are difficult to automate due to their being non-routine. Non-routine manual roles such as cleaners, child care, maintenance, security etc., require to be performed in person, so are challenging to outsource, and non-routine cognitive roles such as solicitors, architects, business analysts and coders - require problem solving skills and employ highly educated workers (Autor 2010).

The continued and growing need for people to fill non-routine cognitive roles such as coders, as well as other jobs in Computer Science and STEM disciplines is challenging. This challenge is particularly pertinent, given the US government (Obama Administration) identifying trends of low enrolments in STEM fields overall, suggesting an eventual dearth of graduates in STEM fields (US Department of Education 2015). Similar observations and resulting recommendations have been made in Canada (Council of Canadian Academies 2015); UK (Department for Business, Innovation and Skills 2016); Brazil (Cooley 2012); and Australia (Department of Education and Training 2015).

A removal or lessening of these diversity barriers to education could have a positive flow-on effect to the pool of available and STEM-qualified workers.

The purpose of this study is to investigate whether the use of Massive Open Online Courses (MOOCs) can reduce some of the diversity gaps compared with formal undergraduate education, with a focus on gender, ethnicity and age. In the following sections, we shall (1) review the relevant literature to discuss how online learning can potentially address diverse student needs, (2) describe our research design and methodology, (3) analyze our data, (4) discuss the practical implications of our data analysis and (5) summarize our findings and identify future research directions. 


\section{LITERATURE REVIEW}

\subsection{Addressing Diversity Gaps in STEM}

Industry reports and the academic literature have offered a number of explanations for the persistence in diversity gaps observed in computing, including insufficient recruitment and retention efforts targeting minority groups (Whittaker and Montgomery 2013); insufficient diversity in faculty members (Towns 2010); subtle discrimination in the workplace and in education (Marder 2012, Moss-Racusin et al 2012); and insufficient incentive for diversity commitment among faculty members (Whittaker and Montgomery 2013).

To address the persistent diversity gaps, organizations have dedicated resources to develop interest among underrepresented minorities at the high school level (Bystydzienski et al 2015, Cheryan et al 2015). E-mentoring has been used to provide underrepresented groups electronic access to mentors who have similar backgrounds in other institutions (Wadia-Fascetto and Leventman 2000, Blake-Beard et al 2011). It is also recommended that tertiary institutions cultivate commitment to diversity by formalization of policies, engagement and accountability (Whittaker and Montgomery 2013). Implicit bias training has also been shown to improve attitudes toward women in STEM (Jackson et al 2014). Various learning methods and interventions have also been found to improve performance disparities among students of different backgrounds including pair programming (McDowell et al. 2006), value affirmation (Miyake et al 2010), structured course design and active learning (Haak et al 2011).

\subsection{Online Learning and Diversity}

Baker et al (2018) conducted a field experiment on an online learning platform where each comment was assigned a student name connoting a specific race and gender and found that instructors were $94 \%$ more likely to respond to White male students. This result suggests that hidden biases exist in even in the online learning environment. On the other hand, Grella and Meinel (2016) found that although only $16 \%$ of those who take part in learning STEM in MOOCs are female, success completion rates are about the same for female $(25 \%)$ and male $(26 \%)$ learners. Furthermore, discussion forum participation, which increases the likelihood of successful completion, is greater among female than male learners. A high level of involvement among female students is also reported in online learning of non-STEM subjects (Cuadrado-Garcia, et al 2010). Drew et al (2015) show that a hybrid online 2+2 STEM program increases participation of underrepresented minority students as compared to a similar traditional face-to-face $2+2$ program. Together, these findings suggest that online learning can potentially be used to resolve some issues that lead to diversity gaps in STEM education.

Wladis et al (2015) show that, compared to face-to-face STEM courses, Black and Hispanic students are significantly underrepresented in online STEM courses. However, females and students with non-traditional student risk factors (such as delayed enrollment, no high school diploma, part-time enrolment, financially independent, have dependents, single-parent status, and working full-time) are significantly overrepresented in online STEM courses. This suggests that the diversity implications of online learning are actually quite complex and require further research attention. 


\subsection{Research Question}

The purpose of this study is to analyze the demographic distribution of students who learn to code on an online platform (MOOC) compared to that of formal undergraduate education. Specifically, our research question is: Are there differences in the demographics of students learning to code online and students acquiring a formal IT-related degree in terms of gender, ethnic minority status and age? The answer to this question will allow us to evaluate the diversity implications of learning to code online, and shed some light on why online learning affects different diversity gaps differently.

\section{RESEARCH METHODOLOGY}

To compare the demographic distributions of online learning and formal undergraduate education, we make use of two publicly available data sources: (1) the 2016 New Coder Survey and (2) the Integrated Postsecondary Education Data System (IPEDS).

The 2016 New Coder Survey was predominantly completed by online self-paced students of Free Code Camp (FCC) and CodeNewbie (CN). FCC is a self-education portal for people who are interested in software development and in learning to code, particularly in web-development programming languages such as HTML, CSS, JavaScript and JQuery among others. $\mathrm{CN}$ is an online community focussed on the support and education of users who are interested in coding. The survey asked up to 43 questions (depending on respondents' answers) covering respondents' learning approach as well as demographic and socio-economic data. 15,620 respondents completed the survey; of these respondents, 6,265 were from the U.S. The survey was completely anonymous, and all questions were non-compulsory. The data can be downloaded from: https://github.com/freeCodeCamp/2016-new-coder-survey.

IPEDS is a system that contains survey data conducted annually by the U.S. Department of Education's National Center for Education Statistics. The surveys collect data such as enrolments, program completions, graduation rates, faculty and staff, finances, institutional prices and student financial data from institutions that participate in federal student aid programs. The data can be downloaded from https://nces.ed.gov/ipeds/use-the-data. To ensure comparability, non-U.S. data from the New Coder Survey are excluded when comparing the demographic distributions between online learning and formal undergraduate education. Since the IPEDS data set does not provide data on computer science enrolment broken down by age and ethnicity, we will compare our New Coder Survey data with the completions data from the IPEDS data set, specifically, degrees awarded under CIP Code 11: Computer and Information Sciences and Support Services in 2016. ${ }^{1}$

The 2016 New Coder Survey was originally analysed and compared with general findings from related research focussed on formal education, as a part of the lead author's master's dissertation (Lane, 2017). This paper endeavours to refocus the survey analysis, by contrasting with comparable survey data from the formal education domain.

\footnotetext{
${ }^{1}$ We use the provisional release data collected in the academic year 2016-2017.
} 


\section{DATA ANALYSIS}

\subsection{Educational Background of Respondents from the New Coder Survey}

Before comparing online learning and formal education, we provide some descriptive statistics on the education background of the respondents of the New Coder Survey (online learning) in Table 1.

Table 1. Highest education attained by respondents from the new coder survey

\begin{tabular}{|l|c|c|}
\hline \multicolumn{1}{|c|}{ Highest Education } & Count (n) & Percentage (\%) \\
\hline No high school (secondary school) & 65 & $1.0375 \%$ \\
\hline Some high school & 194 & $3.0966 \%$ \\
\hline High school diploma or equivalent (GED) & 325 & $5.1875 \%$ \\
\hline Some college credit, no degree & 1304 & $20.8140 \%$ \\
\hline Trade, technical or vocational training & 134 & $2.1389 \%$ \\
\hline Associate's degree & 444 & $7.0870 \%$ \\
\hline Bachelor's degree & 2782 & $44.4054 \%$ \\
\hline Master's degree (non-professional) & 633 & $10.1038 \%$ \\
\hline Professional degree (MBA, MD, JD, etc.) & 279 & $4.4533 \%$ \\
\hline Ph.D. & 79 & $1.2610 \%$ \\
\hline Missing value & 26 & $0.4150 \%$ \\
\hline Total & $\mathbf{6 2 6 5}$ & $\mathbf{1 0 0 \%}$ \\
\hline
\end{tabular}

As shown, over $60 \%$ of the respondents from the New Coder Survey own a higher degree. This is consistent with Ho et al (2015) and Schmid et al (2015) who found that the majority of massive open online course (MOOC) students are college graduates.

\subsection{Online Learning vs. Formal Education: Gender}

The gender distributions from the New Coder Survey (online learning) and IPEDS (formal education) are shown in Table $2 \mathrm{~A}$.

Table 2A. Gender distributions

\begin{tabular}{|l|c|c|c|c|}
\hline \multirow{2}{*}{ Gender } & \multicolumn{2}{|c|}{ Online Learning } & \multicolumn{2}{c|}{ Formal Education (Computer Science Only) } \\
\cline { 2 - 5 } & $\mathbf{n}$ & $\mathbf{\%}$ & $\mathbf{n}$ & $\mathbf{\%}$ \\
\hline Male & 4,369 & $69.737 \%$ & 410,508 & $76.272 \%$ \\
\hline Female & 1,781 & $28.428 \%$ & 127,707 & $23.728 \%$ \\
\hline Other & 94 & $1.500 \%$ & 0 & $0 \%$ \\
\hline Missing value & 21 & $0.335 \%$ & 0 & $0 \%$ \\
\hline Total & $\mathbf{6 , 2 6 5}$ & $\mathbf{1 0 0 \%}$ & $\mathbf{5 3 8 , 2 1 5}$ & $\mathbf{1 0 0 \%}$ \\
\hline
\end{tabular}


If we focus only on the two major groups (i.e., male and female) and perform a z-test to compare the two population proportion, we find that the proportion of females in online learning is significantly different from the proportion of females in formal education $(z=9.2609$, $p<0.001)$.

We noted in Section 4.1 that the majority of our subjects are degree holders. To assess the democratizing effect of online learning, we distinguish between those who majored in an IT-related subject and those who majored in a non-IT related subject. The New Coder Survey asked respondents to specify their major. Of the U.S. sample, a total of 4,158 answered the questions, giving a total of 426 distinct majors specified (e.g., Accounting, Public Health, Women's Studies, etc.). Two of the authors independently classified each of the unique majors into "IT-Related" and "non-IT related" based on the name of the major. Out of the 426 majors, there were 22 discrepancies. Overall, the level of agreement is $94.84 \%$. The Cohen's kappa coefficient is $94.81 \%$, suggested a high inter-rater reliability. For the 22 discrepancies, a third author was asked to make the final decision.

Table 2B. Online learning gender distributions (with and without IT background)

\begin{tabular}{|l|c|c|c|c|}
\hline \multirow{2}{*}{ Gender } & \multicolumn{2}{c|}{$\begin{array}{c}\text { Online Learning (With IT } \\
\text { Background) }\end{array}$} & \multicolumn{2}{c|}{$\begin{array}{c}\text { Online Learning (With no IT } \\
\text { Background) }\end{array}$} \\
\cline { 2 - 5 } & $\mathbf{n}$ & $\mathbf{\%}$ & 1859 & \% \\
\hline Male & 891 & $78.989 \%$ & 1119 & $61.353 \%$ \\
\hline Female & 225 & $19.947 \%$ & 45 & $1.485 \%$ \\
\hline Other & 8 & $0.709 \%$ & 7 & $0.231 \%$ \\
\hline $\begin{array}{l}\text { Missing } \\
\text { value }\end{array}$ & 4 & $0.355 \%$ & & $\mathbf{1 0 0 \%}$ \\
\hline Total & $\mathbf{1 1 2 8}$ & $\mathbf{1 0 0 \%}$ & $\mathbf{3 0 3 0}$ & \\
\hline
\end{tabular}

Focusing only on males and females, z-tests show that the percentage of females among those with an IT background is significantly lower than the overall average of online learning $(1781 /(1781+4369)=28.96 \%)(z=-6.6735, p<0.001)$ and the percentage of females among those without an IT background is significantly higher than the overall average of online learning $(z=9.6740, p<0.001)$. It seems that the democratizing effect of online learning is stronger among those who do not have an IT background. It is also interesting to note that females who already have an IT background are less likely to participate in online coding education than non-IT counterparts. In fact, participation rate of females with an IT background in online learning is even lower than the participation rate of females in formal computer science education $(z=-2.9851, p=0.003)$.

\subsection{Online Learning vs. Formal Education: Ethnic Minority}

The New Coder Survey directly asked whether the respondent is an ethnic minority. The IPEDS divided students into specific ethnic groups (white, American Indian or Alaska native, black or African American, Hispanic or Latino, native Hawaiian or other Pacific islander, nonresident alien, race/ethnic unknown, two or more races). Here, we group all groups other than white as minority. 
COMPUTER SCIENCE AND CODING STUDY PATHS FOR WOMEN, MATURE WORKERS, AND MINORITIES: MOOC OR UNIVERSITY - WHO DOES IT BETTER?

Table 3A. Distributions of ethnic minority status

\begin{tabular}{|c|c|c|c|c|c|}
\hline & \multirow[t]{2}{*}{ Is Ethnic Minority? } & \multicolumn{2}{|c|}{$\begin{array}{c}\text { Online } \\
\text { Learning }\end{array}$} & \multicolumn{2}{|c|}{$\begin{array}{l}\text { Formal Education (Computer } \\
\text { Science Only) }\end{array}$} \\
\hline & & n & $\%$ & $\mathbf{n}$ & $\%$ \\
\hline \multicolumn{2}{|l|}{ No } & 4284 & $68.380 \%$ & 245,463 & $45.607 \%$ \\
\hline \multirow[t]{8}{*}{ Yes } & $\begin{array}{l}\text { American Indian or Alaska } \\
\text { Native }\end{array}$ & \multirow{8}{*}{1936} & \multirow{8}{*}{$30.902 \%$} & 2,736 & $0.508 \%$ \\
\hline & Asian & & & 45,366 & $8.429 \%$ \\
\hline & Black or African American & & & 51,612 & $9.589 \%$ \\
\hline & Hispanic or Latino & & & 52,848 & $9.819 \%$ \\
\hline & $\begin{array}{l}\text { Native Hawaiian or Other } \\
\text { Pacific Islander }\end{array}$ & & & 1,338 & $0.249 \%$ \\
\hline & Nonresident Alien & & & 98,667 & $18.332 \%$ \\
\hline & Race/Ethnic Unknown & & & 26,700 & $4.961 \%$ \\
\hline & Two or More Races & & & 13,485 & $2.506 \%$ \\
\hline \multicolumn{2}{|c|}{ Missing value } & 45 & $0.718 \%$ & 0 & $0 \%$ \\
\hline \multicolumn{2}{|c|}{ Total } & 6265 & $100 \%$ & 538,215 & $100 \%$ \\
\hline
\end{tabular}

If we exclude the missing values from analysis, take the ethnic minority status as a binary variable and perform a z-test to compare the proportions of ethnic minorities, we find that the proportion of ethnic minorities in online learning is significantly different from the proportion of ethnic minorities in formal education $(z=36.8794, p<0.001)$.

Table 3B. Online learning ethnic minority distributions (with and without IT background)

\begin{tabular}{|l|c|c|c|c|}
\hline \multirow{2}{*}{$\begin{array}{c}\text { Is Ethnic } \\
\text { Minority? }\end{array}$} & \multicolumn{2}{c|}{$\begin{array}{c}\text { Online Learning (With IT } \\
\text { Background) }\end{array}$} & \multicolumn{2}{c|}{$\begin{array}{c}\text { Online Learning (With no IT } \\
\text { Background) }\end{array}$} \\
\cline { 2 - 5 } & $\mathbf{n}$ & $\mathbf{\%}$ & $\mathbf{n}$ & \% \\
\hline No & 796 & $70.657 \%$ & 2114 & $69.769 \%$ \\
\hline Yes & 325 & $28.812 \%$ & 898 & $29.637 \%$ \\
\hline Missing value & 7 & $0.621 \%$ & 18 & $0.594 \%$ \\
\hline Total & $\mathbf{1 2 2 8}$ & $\mathbf{1 0 0 \%}$ & $\mathbf{3 0 3 0}$ & $\mathbf{1 0 0 \%}$ \\
\hline
\end{tabular}

From Table 3B, we can see that an IT background does not seem to have a significant effect on ethnic diversity in online learning $(z=0.4988, p=0.6179)$. Even when we include only those who do not have an IT background in our analysis, online learning still seems to discourage ethnic minorities compared to formal education of computer science $(z=26.7654$, $\mathrm{p}<0.001)$

\subsection{Online Learning vs. Formal Education: Age}

The age distribution for students majoring in computer science is not available in the IPEDS data set. However, we have the age distribution for all students enrolled in U.S. tertiary institutions as shown in Table 4A. Comparing the age distributions of online learning and formal education, we find that the largest age group is 25-34 for online learning and 18-21 for formal education, which is not surprising since we have earlier noted that the majority of the learners 
IADIS International Journal on WWW/Internet

from online learning are degree holders. Excluding the missing values and the unknown age category, a $\chi^{2}$ test on the percentage distributions in Table $4 \mathrm{~A}$ shows that the distributions are significantly different $\left(\chi_{9}^{2}=5,783, p<0.001\right)$.

Figure 1A graphically compares the two distributions. As shown, starting from the 25-29 age group, the bars for online learning (orange) are consistently taller than those for formal education (blue). This observation seems to suggest that online learning can help encourage age diversity in computing.

Table 4A. Age distributions

\begin{tabular}{|l|c|c|c|c|}
\hline \multirow{2}{*}{ Age } & \multicolumn{2}{c|}{ Online Learning } & \multicolumn{2}{c|}{ Formal Education } \\
\cline { 2 - 5 } & $\mathbf{n}$ & $\mathbf{\%}$ & $\mathbf{n}$ & $\mathbf{\%}$ \\
\hline Age under 18 & 243 & $3.879 \%$ & $1,880,218$ & $5.848 \%$ \\
\hline Age 18-19 & 174 & $2.777 \%$ & $7,311,886$ & $22.742 \%$ \\
\hline Age 20-21 & 225 & $3.591 \%$ & $6,795,868$ & $21.137 \%$ \\
\hline Age 22-24 & 788 & $12.578 \%$ & $5,373,464$ & $16.713 \%$ \\
\hline Age 25-29 & 1702 & $27.167 \%$ & $4,354,772$ & $13.545 \%$ \\
\hline Age 30-34 & 1258 & $20.080 \%$ & $2,269,636$ & $7.059 \%$ \\
\hline Age 35-39 & 681 & $10.870 \%$ & $1,452,208$ & $4.517 \%$ \\
\hline Age 40-49 & 734 & $11.716 \%$ & $1,701,600$ & $5.292 \%$ \\
\hline Age 50-64 & 347 & $5.539 \%$ & 875,362 & $2.723 \%$ \\
\hline Age 65 and over & 25 & $0.399 \%$ & 101,020 & $0.314 \%$ \\
\hline Age unknown & 0 & $0 \%$ & 35,526 & $0.110 \%$ \\
\hline Missing value & 88 & $1.405 \%$ & 0 & $0 \%$ \\
\hline Total & $\mathbf{6 2 6 5}$ & $\mathbf{1 0 0 . 0 0 0 \%}$ & $\mathbf{3 2 , 1 5 1 , 5 6 0}$ & $\mathbf{1 0 0 . 0 0 0 \%}$ \\
\hline
\end{tabular}

\section{Online Learning vs Formal Education: Age Distribution}

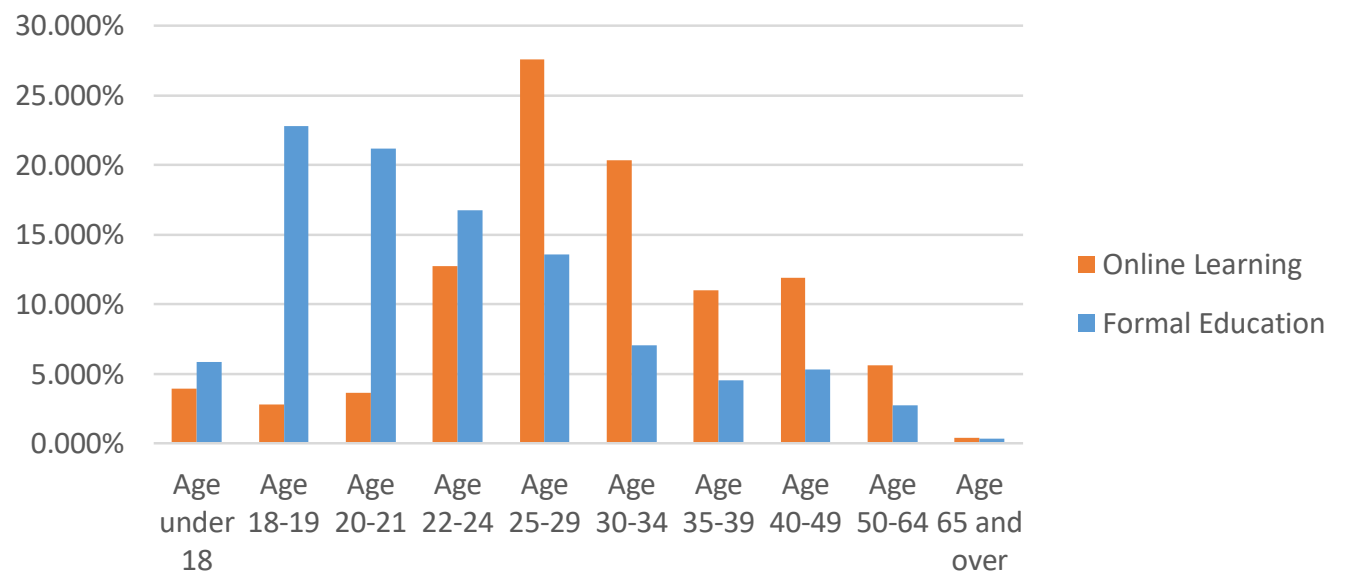

Figure 1A. Age distributions of online learning and formal education 


\section{COMPUTER SCIENCE AND CODING STUDY PATHS FOR WOMEN, MATURE WORKERS, AND MINORITIES: MOOC OR UNIVERSITY - WHO DOES IT BETTER?}

To evaluate the effect of an IT background on age diversity in online learning, we produce Table 4B and Figure 1B. Referring to the orange (Online learning with IT Background) and yellow (Online learning with No IT background) bars in Figure 1B, the difference between the age distributions seems to be smaller than those between online learning and formal education. However, it is still statistically significant $\left(\chi_{9}^{2}=38.78, p<0.001\right)$. Among those with no IT background we observe a larger proportion of learners between 25 and 34 but a smaller proportion of learners between 35 and 49. Overall, an independent sample $t$-test reveals that the mean age between those with and without an IT background is not statistically significant $(t=1.1773, p=0.2392)$. Therefore, it is difficult to say whether online learning has a greater age diversity implication among people with or without an IT background.

In Figure 1B, we can see that both online learning groups have an age distribution that is significantly different from that of formal education (online learning with IT background: $\chi^{2}{ }_{9}=1318, p<0.001$; online learning without IT background: $\left.\chi^{2}{ }_{9}=4274, p<0.001\right)$. In other words, a greater age diversity is observed in online learning regardless of IT background.

Table 4B. Online learning age distributions (with and without IT background)

\begin{tabular}{|l|c|c|c|c|}
\hline \multirow{2}{*}{ Age } & \multicolumn{2}{c|}{$\begin{array}{c}\text { Online Learning (With IT } \\
\text { Background) }\end{array}$} & $\begin{array}{c}\text { Online Learning (With no IT } \\
\text { Background) }\end{array}$ \\
\cline { 2 - 5 } & $\mathbf{n}$ & $\mathbf{\%}$ & $\mathbf{n}$ & \% \\
\hline Age under 18 & 1 & $0.0887 \%$ & 1 & $0.0330 \%$ \\
\hline Age 18-19 & 6 & $0.5319 \%$ & 2 & $0.0660 \%$ \\
\hline Age 20-21 & 25 & $2.2163 \%$ & 25 & $0.8251 \%$ \\
\hline Age 22-24 & 164 & $14.5390 \%$ & 361 & $11.9142 \%$ \\
\hline Age 25-29 & 327 & $28.9894 \%$ & 941 & $31.0561 \%$ \\
\hline Age 30-34 & 221 & $19.5922 \%$ & 738 & $24.3564 \%$ \\
\hline Age 35-39 & 143 & $12.6773 \%$ & 367 & $12.1122 \%$ \\
\hline Age 40-49 & 149 & $13.2092 \%$ & 363 & $11.9802 \%$ \\
\hline Age 50-64 & 67 & $5.9397 \%$ & 183 & $6.0396 \%$ \\
\hline Age 65 and over & 4 & $0.3546 \%$ & 17 & $0.5611 \%$ \\
\hline Missing value & $\mathbf{2 1}$ & $1.8617 \%$ & $\mathbf{3 2}$ & $1.0561 \%$ \\
\hline Total & $\mathbf{1 1 2 8}$ & $\mathbf{1 0 0 \%}$ & $\mathbf{2 9 9 8}$ & $\mathbf{1 0 0 \%}$ \\
\hline
\end{tabular}




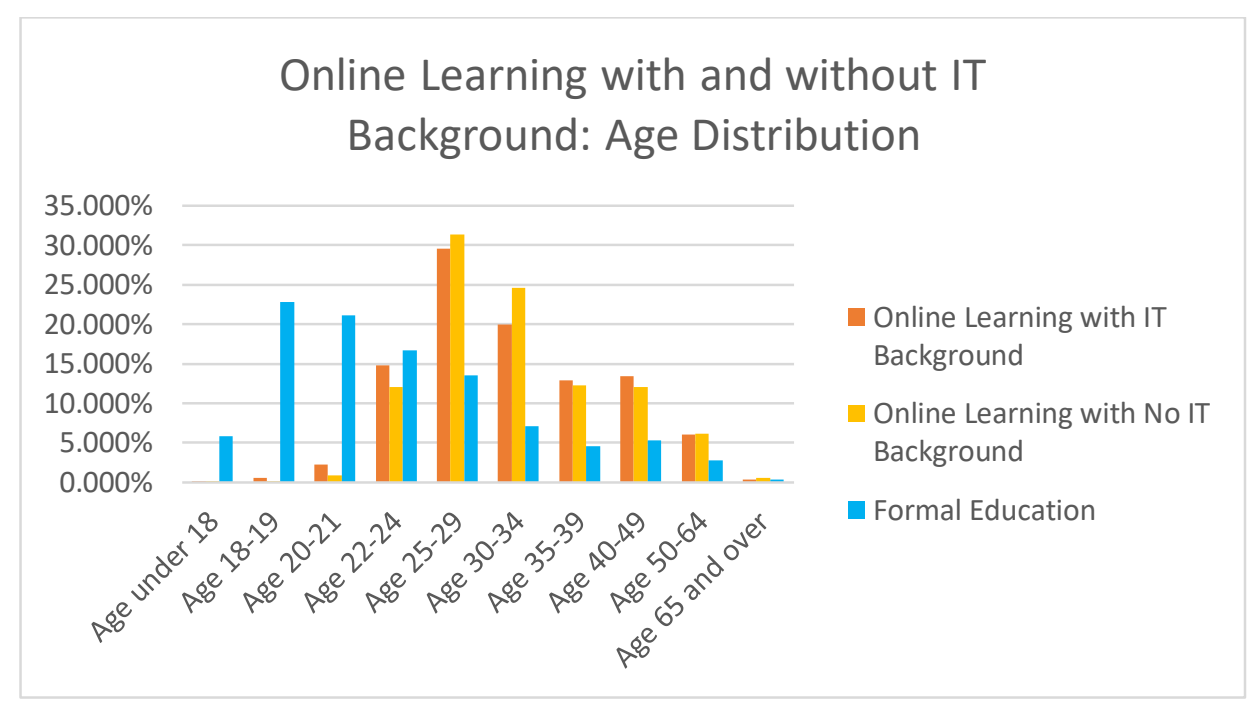

Figure 1B. Age distributions of online learning respondents with and without IT background

\section{PRACTICAL IMPLICATIONS}

Our analysis has shown that online learning can potentially be used to promote a greater diversity in computing disciplines. Females without an IT background and people over 25 may find online coding education more accessible than formal tertiary education, which is consistent with Wladis et al (2015) and Johnson et al (2015). However, online learning seems to have a negative impact on diversity in terms of ethnicity, again consistent with Wladis et al (2015).

One explanation for the negative impact on ethnic diversity, is that the possible language barrier that some learners of ethnic minority may face in a predominantly English-speaking learning platform, where social cues that assist interpretation are generally lacking. Johnson et al (2015) reported a significant lower proportion of speakers of English as a foreign language in online learning compared to on-campus university students, and argued that students who are in the process of enculturation may prefer to acquire language proficiency and cultural familiarity through on-campus education. Google Inc. and Gallup Inc. (2016) suggest ethnic minorities face both social and structural barriers in access and exposure to computer science. It is important for us to understand the drivers behind the observed differences between online learning and traditional face-to-face learning, and design online learning platforms that promote diversity.

It is also important to be aware that the drivers that affect diversity may also change over time. For example, earlier studies have suggested online learning may put female students in a disadvantaged position because they tend to have lower computer self-efficacy (Shashaani 1997, Thompson and Lynch 2003) and prefer face-to-face communication (Anderson 1997). However, the gender difference in computer self-efficacy among digital natives these days has mostly disappeared (Price 2006) and hence computer self-efficacy as a barrier for female students to adopt online learning is no longer a valid argument. In fact, more recent studies have shown that female students tend to benefit more than their male counterparts from social interaction within 
the learning platform (Johnson 2011). Our findings also show that female participation in online coding education is higher than that of formal computer science education. However, our data sets are not capable of validating the hypothesis that opportunity to socially interact on an online platform increases the female participation rate.

We found that the female participation rate in online coding education among those with an IT background is significantly lower than that in formal education of computer science, suggesting that female computer science graduates are less likely to upgrade their coding skills online. This finding is in line with the industry report that female graduates of STEM are less likely to persist in STEM jobs due to various reasons such as family constraints (Glass et al 2013) and dissatisfaction with pay and promotion (Hunt 2016). Further investigation into ways to improve retention of females in computer science in the job market is recommended.

\section{CONCLUSION}

Lack of diversity in Information Technology disciplines such as computer science, and more broadly with STEM-related disciplines is a common problem in many societies. This study compares of the demographic distributions of data collected from the 2016 New Coder Survey with that obtained from the Integrated Postsecondary Education Data System (IPEDS). The findings suggest that female and mature learners were more likely to engage in online self-paced coding education, whereas those who identify as an ethnic minority were less likely to undertake online coding study. The practical implications of this analysis are reflected in the opportunities that it suggests.

Female participation in Information Technology-related disciplines such as computer science falls well behind male participation. Those institutions looking to increase female participation would be encouraged to provide a more supportive environment to cultivate female interest. The research points to a greater percentage of females seeking the comfort of self-paced online learning when looking to engage in computer science as a novice.

A similar observation can be made regarding mature aged students. If tertiary institutions are looking to expand their offering, rather than looking to markets further afield, they need only consider marketing to, and providing a supportive environment for older students looking to return to tertiary study, or to attempt it for the first time, as a means to upskill.

To encourage participation in online study by those who identify as an ethnic minority, more may need to be done to provide lessons or other external support in languages other than English. Where formal tertiary study has the benefit of fostering communication within student groups, online learning can possibly be more difficult for a non-native speaker of the majority language.

Industry too has an obligation, as well as an opportunity to encourage participation in STEM learning. It would be in the interest of industry to advocate for education pathways that suit the needs of mature-age workers seeking to upskill, females, and ethnic minorities, to meet resourcing needs in an ever-changing technological environment. Catering for the education needs of these diverse groups could mean a greater pool of STEM graduates in the future.

Study into self-paced, online learners in this new education paradigm of Massive Open Online Courses, as an alternative to formal tertiary study is in its infancy and this research seeks to highlight some similarities and differences within the demographics of online and traditional tertiary courses. 
IADIS International Journal on WWW/Internet

\section{REFERENCES}

Ali, MM 2001, 'Evolution of Concrete Skyscrapers: from Ingalls to Jin mao', Electronic Journal of Structural Engineering 2-14.

Anderson, T 1997, 'Integrating Lectures and Electronic Course Materials', Innovations in Education and Training International, 34(1), pp. 24-31.

Autor, D 2010, 'The polarization of job opportunities in the U.S. labor market: Implications for employment and earnings', Discussion Paper, Washington: Brookings Institution Press. Available from: https://search-proquestcom.dbgw.lis.curtin.edu.au/docview/845241447?accountid=10382 [19 May 2017].

Ayers, W, Quinn, TM \& Stovall, D 2008, Handbook of Social Justice in Education, Taylor \& Francis Group.

Baker, R, Dee, T, Evans, B \& John, J 2018, 'Bias in Online Classes: Evidence from a Field Experiment', Stanford Center for Education Policy Analysis Working Paper No. 18-03. Available from: http://cepa.stanford.edu/sites/default/files/wp18-03-201803.pdf. [19 June 2018].

Bial, D 2016, 'Diversity in the Workplace Starts with Diversity in Higher Education', Forbes.com. Available from: https://www.forbes.com/sites/schoolboard/2016/03/30/diversity-in-the-workplacestarts-with-diversity-in-higher-education/\#33108a6e5d98. [12 June 2018].

Blake-Beard, S, Bayne, ML, Crosby, FJ \& Muller, CB 2011, 'Matching by Race and Gender in Mentoring Relationships: Keeping Our Eyes on the Prize', Journal of Social Issues, 67, pp. 622-643.

Bourgeois, T 2018. 'The Role of Education in Advancing a Diversity and Inclusion Breakthrough: Linking Education to the Workforce of the Future', Huffingtonpost.com. Available from: https://www.huffingtonpost.com/entry/the-role-of-education-in-advancing-a-diversityand_us_5a556ad1e4b0baa6abf16267. [12 June 2018].

Bystydzienski, J M., Eisenhart, M., Bruning, M 2015, 'High School Is Not Too Late: Developing Girls' Interest and Engagement in Engineering Careers', Career Development Quarterly, 63(1), 88-95.

Castillo, M 2017, '35 Isn't Too Old to Work in Tech — But You May Feel over the Hill, Say Software Engineers', CNBC Tech. Available from: https://www.cnbc.com/2017/09/18/even-35-year-olds-mayfeel-ageism-in-tech-google-amazon-engineers.html. [13 June 2018].

Cheryan, S, Master A, Meltzoff AN, 2015, 'Cultural Stereotypes as Gatekeepers: Increasing Girls' Interest in Computer Science and Engineering by Diversifying Stereotypes', Frontiers in Psychology. Available from: https://www.frontiersin.org/articles/10.3389/fpsyg.2015.00049/full. [15 June 2018].

Claburn, T, 2018, 'Facebook Caught Up in Court Battle with Amazon and Pals over 'Ageist Job Ads' that Targeted Young', The Register. Available from: https://www.theregister.co.uk/2018/05/29/facebook_adverts_age_discrimination_lawsuit/. [13 June 2018].

Cohen, D \& Cosentino, C 2009, 'Retention Is Not the Problem', ASEE Prism, 19(2), p. 55.

Cooley, T 2012, 'Brazil Reaches Beyond Borders to Strengthen STEM Education', 31 July, BIOtechNOW, Available from: https://www.biotech-now.org/corporate/2012/07/brazil-reaches-beyond-borders-tostrengthen-stem-education. [7 May 2017].

Corday, R, 2014, 'The evolution of assembly lines: A brief history' 24 April, Robohub Available from: http://robohub.org/the-evolution-of-assembly-lines-a-brief-history/. [19 May 2017].

Council of Canadian Academies, 2015, 'Some Assembly Required: STEM Skills and Canada's Economic Productivity.', Ottawa (ON): The Expert Panel on STEM Skills for the Future.

Cuadrado-Garcia, M., Ruiz-Molina, M-E, \& Montoro-Pons, JD, 2010, 'Are There Gender Differences in E-Learning Use and Assessment? Evidence from an Interuniversity Online Project in Europe', Procedia Social and Behavior Sciences, 2, pp. 367-371. 


\section{COMPUTER SCIENCE AND CODING STUDY PATHS FOR WOMEN, MATURE WORKERS, AND MINORITIES: MOOC OR UNIVERSITY - WHO DOES IT BETTER?}

Department for Business, Innovation and Skills, 2016, 'Johnson sets out measures to make UK best place in world to do science', 27 January. Available from: https://www.gov.uk/government/news/johnsonsets-out-measures-to-make-uk-bestplace-in-world-to-do-science. [5 May 2017].

Department of Education and Training, 2015, 'Restoring the focus on STEM in schools initiative', 1 December. Available from: https://www.studentsfirst.gov.au/restoring-focusstem-schools-initiative. [7 May 2017].

Drew, J C, Oli, MW, Rice, KC, Ardissone, AN, Galindo-Gonzalez, S, Sacasa, PR, Belmont, HJ, Wysocki, AF, Rieger, M \& Triplett, EW, 2015, 'Development of a Distance Education Program by a Land-Grant University Augments the 2-Year to 4-Year STEM Pipeline and Increases Diversity in STEM', PLoS ONE, 10(4).

Glass, J, Sassler, S, Levitte, Y \& Michelmore, K, 2013, 'What's So Special about STEM? A Comparison of Women's Retention in STEM and Professional Occupations', Social Forces, 92, pp. 723-756.

Glick, B 2017, '”Depressing” Lack of Diversity in UK IT Workforce Sees Widespread Discrimination', ComputerWeekly.com. Available from: https://www.computerweekly.com/news/450430980/Depressing-lack-of-diversity-in-UK-ITworkforce-sees-widespread-discrimination. [13 June 2018].

Google Inc. \& Gallup Inc, 2016 'Diversity Gaps in Computer Science: Exploring the Underrepresentation of Girls, Blacks and Hispanics', Available from: https://services.google.com/fh/files/misc/diversitygaps-in-computer-science-report.pdf. [27 June 2018].

Grella, C \& Meinel, C 2016, 'MOOCs as a Promoter of Gender Diversity in STEM?', The 12 ${ }^{\text {th }}$ International Scientific Conference eLearning and Software for Education Bucharest, April 21-22, 2016.

Guynn, J 2016, 'Google: Race, Gender Gaps Persist in Computer Science Education', USA Today. Available from: https://www.usatoday.com/story/tech/news/2016/10/18/google-gallup-computerscience-girls-blacks-hispanics/92335498/. [13 June 2018].

Haak, DC, HilleRisLambers, J, Pitre, E \& Freeman, S, 2011, 'Increased Structure and Active Learning Reduce the Achievement Gap in Introductory Biology', Science, 332(6034), pp. 1213-1216.

Heath, A, 2016, 'The Changing Nature of the Australian Workforce', CEDA - Future Skills The Education and Training Pipeline. Brisbane: Committee for Economic Development of Australia.

Ho, AD, Chuang, I, Reich, J, Colman, C, Whitehill, J, Northcutt, C, Williams, JJ, Hansen, J, Lopez, G \& Petersen, R, 2015, 'HarvardX and MITx: Two Years of Open Online Courses', HarvardX Working Paper No. 10. Doi:10.2139/ssrn.2586847.

Hunt, J, 2016, 'Why do Women Leave Science and Engineering?', ILR Review, 69, pp. 199-226.

Jackson, SM, Hillard, AL \& Schneider, TR, 2014, 'Using Implicit Bias Training to Improve Attitudes toward Women in STEM', Social Psychology of Education, 17(3), pp. 419-439.

Johnson, RD, 2011, 'Gender Differences in E-Learning: Communication, Social Presence, and Learning Outcomes', Journal of Organizational and End User Computing, 23(1), pp. 79-94.

Kendall, G, 2017, 'Here's Why There's a Gender Gap in Computer Science', World Economic Forum. Available from: https://www.weforum.org/agenda/2017/01/heres-why-theres-a-gender-gap-incomputer-science. [13 June 2018].

Lane, MA, 2017, 'Learning to Code Online: Factors Contributing to Actual or Expectation of Success - An Exploratory Survey Analysis Across Six Countries', Master's Dissertation, Curtin University. Available from: http://www.members.iinet.net.au/ matlane/codeprojectimg/Dissertation.pdf. [6 October 2017].

Leggatt, J, 2016, 'Driverless tractors: Future of robotic farming takes shape', 15 November. Available from: http://www.weeklytimesnow.com.au/machine/crop-gear/driverless-tractors-future-ofroboticfarming-takes-shape/news-story/1c3593805e94346c353c7c929a94a6cc. [19 May 2017]. 
IADIS International Journal on WWW/Internet

Marder, J, 2012, 'Why the Engineering, Computer Science Gender Gap Persists', Scientific American. Available from: https://www.scientificamerican.com/article/why-the-engineering-and-sciencegender-gap/. [14 June 2018].

McDowell, C, Werner, W, Bullock, HE \& Fernald, J, 2006, 'Pair Programming Improves Student Retention, Confidence, and Program Quality', Communications of the ACM, 49(8), 90-95.

Mcintyre, DA, 2018, 'IBM Hit with Massive Age Discrimination Charges, Undermining CEO Rometty', 247WallStreet. Available from: https://247wallst.com/technology-3/2018/03/23/ibm-hit-withmassive-age-discrimination-charges-undermining-ceo-rometty/. [13 June 2018].

McLeod, PL, Lobel, SA \& Cox, Jr, TH, 1996, 'Ethnic Diversity and Creativity in Small Groups', Small Group Research, 27(2), 248-264.

Miliszewska, I, Barker, G, Henderson, F \& Sztendur, E, 2006, 'The Issue of Gender Equity in Computer Science - What Students Say', Journal of Information Technology Education, 5, 107-120.

Miyake, A, Kost-Smith, LE, Finkelstein, ND, Pollock, SJ, Cohen, GL \& Ito, TA, 2010, 'Reducing the Gender Achievement Gap in College Science: A Classroom Study of Value Affirmation', Science, 330(6008), pp. 1234-1237.

Moss-Racsuin, CA, Dovidio, JF, Brescoll, VL, Graham, MJ \& Handelsman, J, 2012, 'Science Faculty's Subtle Gender Biases Favor Male Students', Proceedings of the National Academy of Sciences of the United States of America, 109(41): 16474-16479.

Østergaard, CR, Timmermans, B \& Kristinsson, K, 2011, 'Does a Different View Create Something New? The Effect of Employee Diversity on Innovation', Research Policy, 40(3), 500-509.

Price, L 2006, 'Gender Differences and Similarities in Online Courses: Challenging Stereotypical Views of Women', Journal of Computer Assisted Learning, 22(5), pp. 329-359.

Robbins, S, 2004, 'Why Diversity Is an Opportunity', Harvard Business School Working Knowledge. Available from: https://hbswk.hbs.edu/archive/why-diversity-is-an-opportunity. [12 June 2018].

Schmid, L, Manturuk, K, Simpkins, I, Goldwasser, M \& Whitfield, KE, 2015, 'Fulfilling the Promise: Do MOOCs Reach the Educationally Underserved?' Educational Media International, 52(2), pp. 116-128.

Serrels, M, 2018, 'The Subtle Demon: The Games Industry's Problem with Ageism', Kotaku. Available from: https://www.kotaku.com.au/2018/01/the-subtle-demon-the-games-industrys-problem-withageism/. [13 June 2018].

Sethna, BN, 2011, 'Minorities in Higher Education: A Pipeline Problem?', Research in Higher Education Journal, 13, pp. 1-18.

Sue, DW, 2008, 'Multicultural Organizational Consultation: A Social Justice Perspective', Consulting Psychological Journal: Practice and Research, 60(2), 157-169.

Sumagaysay, L, 2017, 'Survey: Almost Half of Tech Workers Worry about Losing Their Jobs Because of Ageism', SiliconBeat. Available from: http://www.siliconbeat.com/2017/10/19/survey-almost-halfof-tech-workers-worry-about-losing-their-jobs-because-of-ageism/. [13 June 2018].

Taylor, VE, \& Ladner, RE, 2012 'Where are the Minorities in Computing?' Computing Research News, Computing Research Association. Available from: https://cra.org/crn/2012/03/where_are_the_minorities_in_computing1/. [13 June 2018].

Thompson, LF, \& Lynch, BJ, 2003, 'Web-Based Instruction: Who is Inclined to Resist It and Why?' Journal of Educational Computing Research, 29(3), pp. 375-385.

Towns, MH, 2010, 'Where Are the Women of Color? Data on African American, Hispanic, and Native American Faculty in STEM', Journal of College Science Teaching, March/April 2010, pp. 8-9.

UNESCO, 2017, 'Women Still a Minority in Engineering and Computer Science', Natural Sciences Sector, United Nations Educational, Scientific and Cultural Organization. Available from: http://www.unesco.org/new/en/unesco/themes/gender-equality/resources/single-viewgender/news/women_still_a_minority_in_engineering_and_computer_science/. [13 June 2018]. 


\section{COMPUTER SCIENCE AND CODING STUDY PATHS FOR WOMEN, MATURE WORKERS, AND MINORITIES: MOOC OR UNIVERSITY - WHO DOES IT BETTER?}

US Department of Education, 2015, 'Science, Technology, Engineering and Math: Education for Global Leadership', Available from: https://www.ed.gov/stem. [5 May 2017].

Wadia-Fascetti, S \& Leventman, PG, 2000, 'E-Mentoring: A Longitudinal Approach to Mentoring Relationships for Women Pursuing Technical Careers', Journal of Engineering Education, 89, pp. 295-300.

Wells, G, 2018, 'Intel Faces Age-Discrimination Claims', Wall Street Journal. Available from: https://www.wsj.com/articles/intel-faces-age-discrimination-claims-1527264300?mod=e2twd. [13 June 2018].

Wladis, C, Hachey, AC \& Conway, KM, 2015, 'The Representation of Minority, Female, and Non-Traditional STEM Majors in the Online Environment at Community Colleges: A Nationally Representative Study', Community College Review, 43(1), pp. 89-114. 